\title{
USING GIS TO MAPPING DISSEMINATION AND PREDICTION OF POPULATION IN BANDUNG CITY
}

\author{
MUNIR ${ }^{1}$, Beta PARAMITA ${ }^{2}$, Robby ANGGARA ${ }^{1}$, Lala Septem RIZA ${ }^{1}$, \\ Wayan SUPARTA ${ }^{3}$
}

DOI: $10.21163 / G T \_2020.151 .26$

\begin{abstract}
:
Bandung, the capital of West Java, is the province with the largest population in Indonesia.Urban development is then interrelated with the number, structure, dynamics of the population, also the size of the area. The pattern of population distribution is an important point for the government in determining a City's Spatial Plan. Thus, this study aims to build a mapping system for population distribution and prediction in Bandung City, Indonesia. It will be very beneficial for the government, especially in making decisions for planning an area. The system implemented using the Google Maps platform APIs and the method of calculating Geometric models and processed data is data obtained from the Central Bureau of Statistics of the city of Bandung in the form of a sub-district catalogue in the reprocessed numbers. The results of the data processing are visualized into the Geographic Information System Web with information features in the form of population mapping, density, and prediction of the future population for each sub-district in the city of Bandung. Based on the results of testing the implementation of the Geometry model with the Black box method, the system's functionality has shown the appropriate results.
\end{abstract}

Key-words: GIS, population prediction, Bandung, Geometric Method

\section{INTRODUCTION}

Bandung is the capital city of West Java Province, the most populous province in Indonesia. The population growth rate in Bandung hits $1.06 \%$ a year. By carrying out the Smart City concept, the City of Bandung continues to strive to develop information and communication technology infrastructure in various fields, including government, transportation, environment, finance, education, health, security, community development, trade, and business, also known as e-government. Those concept as a model of government service by utilizing information and communication technology resources to serve the needs of the community (Howard, 2001). In addition to carrying the Smart City concept, the city of Bandung itself has a lot of attraction which is the cause of the movement of people from the villages and from outside the area to the city so that it is difficult to control and resulted in an increase in the population of each sub-district in the city. Population density often causes problems in spatial arrangement due to the large population pressure on land (Malik, Suparta, \& Dewancker, 2019). In areas with dense population and uneven distribution, it will face problems such as housing problems, employment problems, education problems, food problems, security problems and can have an impact on environmental damage. Previous study about compact city in Bandung shows that Sub-district of Cibeunying becomes the

\footnotetext{
${ }^{1}$ Universitas Pendidikan Indonesia, Department of Computer Science Education, Bandung, Indonesia,munir@upi.edu,anggararobby18@gmail.com,lala.s.riza@upi.edu

${ }^{2}$ Universitas Pendidikan Indonesia, Department of Architecture Education Bandung, Indonesia, betaparamita@upi.edu

${ }^{3}$ Universitas Pembangunan Jaya, Department of Informatics, South Tangerang City, Banten 15413, Indonesia, Corresponding author: wayan.suparta@upj.ac.id
} 
center of public facilities. It led the concentration of density and activity, which finally raising the slum and overcrowded settlement (Paramita, 2016). This is also inline with the study in Namibia, South Africa that the complex spatial structures constructed by density, urban development and a mixture of human activity as well as high population mobility has successfully developed (Zee and Jong, 1999).

These problems can be more easily solved by the existence of a system, for example making a site or web based on the Geographic information system (GIS) where population data, population density, and prediction are made in the form of web-based mapping that can facilitate access to data and information. Observation of patterns of population distribution in an area is used so that the government can make the right decision to carry out development in the area in accordance with the existing population. The importance of population distribution in the form of mapping can be useful to demonstrate changes in the human population (Chen et al., 2018). An information system in the form of an urban hazard information infrastructure (UHII) as data management for spatial decision-making, controlling urban development, and emergency response planning in the city of Windhoek

Data and information about population conditions such as population and projections in an area are needed in the framework of development planning in all fields. By knowing the number of needs in the future, the government can take policies or plan in providing land for settlements so that the development of settlements and other aspects in the future does not violate their designation and in accordance with the city's spatial plan. The use of GIS and Database Management System (DBMS) later created to gain an easier management, storage and review of data (Costantino et al., 2016). It is able to give information in different ways by represent a useful basis and an operative support. For example, a GIS called the Douglas County Emergency Management Agency (DCEMA) was developed to maintain and implement an integrated emergency management system where GIS act as decision-makers to develop a flood impact assessment and project the possibilities (Gunes \& Kovel, 2000).

GIS stores georeferenced historical maps and it is able for assessing its development changes due both to natural or catastrophic events such as earthquakes (Baiocchi et al., 2013; Brigante \& Radicioni, 2014). The study in the city of Cardiff as the capital city of the state of Wales, UK examines the effect of alternative population distribution models on the analysis of the spatial accessibility of GIS. It shows variation inaccessibility of the number of public services in the city where the results of these tests are used to inform city planning, provision of public facilities, and allocation of spatial financial resources (Langford et al., 2008). Mapping the quality of education through the education facilities location with GIS in order to make improvements and to increase public awareness of the importance of education (Shah \& Nerurkar, 2012; Harison \& Syarif, 2016). Mapping of distribution and analysis was also carried out for agricultural land. The results in the form of web-based, geographic information can display information on agricultural results, rainfall, and land height from sea level. This information is beneficial to analyze the soil types then to recommend the agricultural products (Rahmawati, Saputra \& Sugiharto, 2014; Susanto, Kharis \& Khotimah, 2016). The population projection is carried out aimed at assessing the level of population density and its distribution and reviewing population projections and housing needs. The level of population density is calculated based on the population per settlement area and the calculation of population projections is done using geometric methods. This method is used because the data on fertility (birth) and mortality is limited so that it is assumed that the factors that influence the growth of the permanent population are the same growth rates for each year. 


\section{METHODS}

The research design is a depiction of the steps taken in conducting a research, the design in this study can be seen in Fig. 1. Starting from a literature study on previous research, continued with quantitative data collection and spatial data in Bandung city, then system requirements analysis to support research, system design includes the design process in the system and system interfaces, implementation of system design results with map digitization, database, and coding program, enter the stage of testing and analysis of test results to determine the system's functionality.

For the data obtained from the catalog such as sub-districts in the numbers derived from the city Central Statistics Agency and also some data obtained from the website of each subdistrict in the city of Bandung for the past five years from 2013-2017 with a total of 150 reprocessed data and spatial data of Bandung city and its sub-districts in the form of coordinate points. The following population data numbers 2017 are used as a reference to project the population that will come to Table 1.

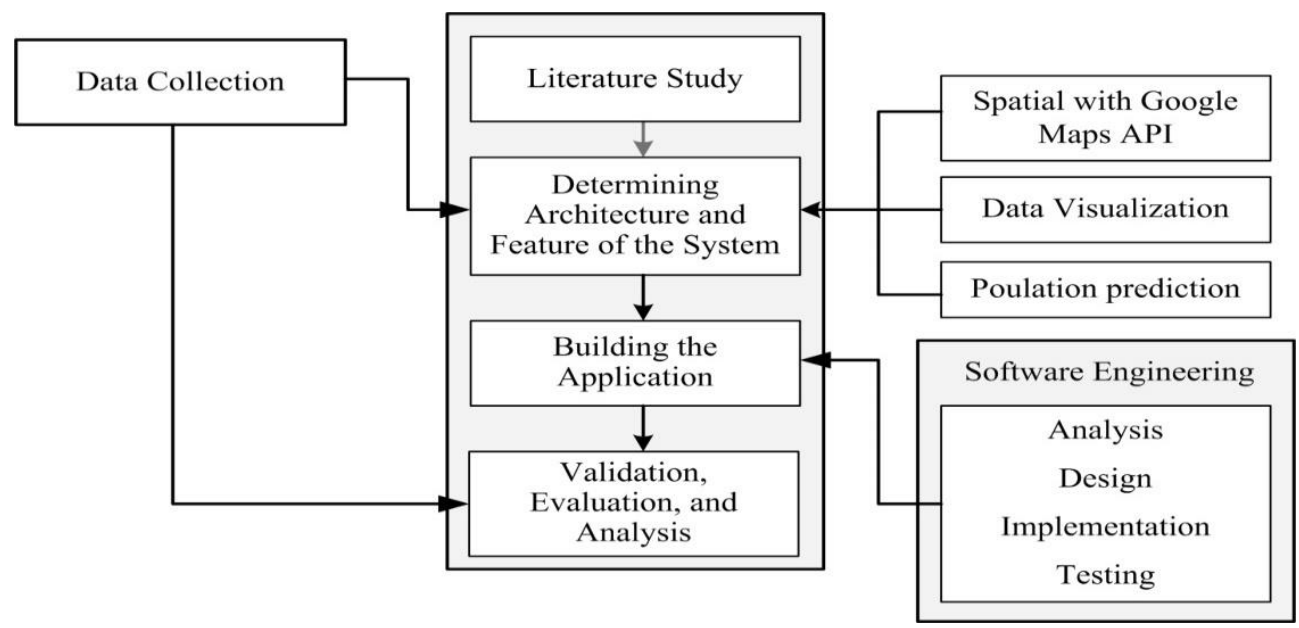

Fig. 1. The framework of dissemination and pediction of population using GIS.

To present the results of calculations in the form of mapping, it is necessary to configure the spatial data in the form of layers in the local database with the Google maps API server so that the results can be seen in the browser. Google maps API is used because Google maps have an API that can be easily used for web-based GIS applications or webgis as a base map or base map so that applications can be easily developed again and Google maps feature that is always updated every time.

Before configuring the layer, it is necessary to have a class identification which is then used to determine the interval of data that has been obtained so that it can be displayed in the form of statistics that are interpreted in the form of coloring so that the user can easily read information about the situation from the amount of population distribution. In determining the class must be known the amount of data to be processed, and then turned into Sturges formula as follows:

$$
\text { class }=1+3.3 \log (n)
$$


Population on Bandung in 2017.

Table 1.

\begin{tabular}{|l|r|l|r|}
\hline Names of districts & Population & \multicolumn{1}{|c|}{ Names of districts } & Population \\
\hline Andir & 104.962 & Cicendo & 98.324 \\
\hline Antapani & 74.557 & Cidadap & 49.931 \\
\hline Arcamanik & 46.774 & Cinambo & 23.376 \\
\hline Astanaanyar & 70.205 & Coblong & 113.89 \\
\hline Babakan Ciparay & 114.265 & Gedebage & 33.198 \\
\hline Bandung Kidul & 47.956 & Kiaracondong & 142.342 \\
\hline Bandung Kulon & 143.313 & Lengkong & 71.333 \\
\hline Bandung Wetan & 38.066 & Mandalajati & 63.147 \\
\hline Batununggal & 114.330 & Panyileukan & 35.040 \\
\hline Bojongloa Kaler & 119.025 & Rancasari & 67.483 \\
\hline Bojongloa Kidul & 47.956 & Regol & 83.404 \\
\hline Buahbatu & 89.555 & Sukajadi & 108.892 \\
\hline Cibeunying Kaler & 87.068 & Sukasari & 80.971 \\
\hline Cibeunying Kidul & 87.068 & Sumur Bandung & 34.411 \\
\hline Cibiru & 61.707 & Ujung Berung & 75.477 \\
\hline
\end{tabular}

Source: Bandung in Figure 2017

For example, the number of classes obtained based on formula (1) with the number of data (n) of 30 districts in the city of Bandung is obtained $5.78 \cong 6$ classes. Then determine the interval for each class to be easier in classifying each region to be interpreted in color. So that the user can read information related to population density according to the interval interpreted into the color. Intervals are determined by the following formula:

$$
\text { Intervals }=\frac{\text { Max }- \text { Min }}{\text { Number of Class }}
$$

The minimum value is obtained from the minimum population in 2017 , while the maximum data is obtained from the prediction of the largest population in the projection period of the next 30 years. There are several ways to project the future population including using mathematical methods and component methods. In this study using mathematical methods in calculating population projections using geometric methods, geometric methods are used because of the assumption that the population will increase geometrically using the basis of compound interest calculations. In other words, the gradual growth takes into account population growth only at the end of the year from a period. The following formula is used in calculating geometric methods:

$$
P_{t}=P_{0}(1+r)^{t}
$$

where $\mathrm{P}_{t}$ is population in year $t, \mathrm{P}_{0}$ is population in the base year, $\mathrm{r}$ is population growth rate, and $\mathrm{t}$ is the time period between base year and year $t$ (in year).

If the minimum and maximum value has been determined and has determined the interval for each class then it will be entered into the frequency distribution table for the distribution of population obtained based on the calculation results with the number of classes (K) 6 and the number of population intervals in each class totaling 33,619.05. 


\section{RESULT AND DISCUSSION}

\subsection{The Architecture of System}

In web-based geographic information to be able to communicate with different components in the web environment, a web server is needed. Because the standard of geo data is different and very specific, the development of the system architecture follows the Client Server architecture. Fig. 2 shows the geographic information system architecture. The application is on the client side that communicates with the server as a data provider through web protocols such as Hyper Text Transfer Protocol (HTTP). The Web Server is responsible for the request process from the client and sends a response to the response. In web architecture, a web server also manages communication with server-side GIS Components. In this case, the GoogleMaps API server is responsible for connections to spatial databases such as translating queries and making representations passed to the server. To manage geographic data, a DBMS is needed by using a database server such as xampp. In this case, object-oriented modeling is also needed because relational database modeling is not able to store geospatial object data consisting of spatial data information and non-spatial data. Spatial information can be visualized by converting it to Virtual Reality Modeling Language (VRML) and non-spatial data is displayed dynamically in the Hypertext Markup Language (HTML).

When the client requests, the connection is made to the DBMS, then the spatial information selected from DBMS is converted into VRML and the Plug-In Browser on the client side displays VRML output as output become a map.

\subsection{Implementation}

In this study, the end result was in the form of a GIS mapping the distribution and prediction of the population in the web-based city of Bandung as follows:

\section{a. Homepage interface}

When the system is first accessed, the system raises the main page, the page is displayed in Fig. 3. Basically it shows the name of the system, the navigation bar, Bandung's view along with a short description of Bandung, and an icon about system information.

\section{b. $\quad$ Modeling page interface}

The next page is the modeling page, which is shown in Fig. 4, and this page contains a line chart of information on population growth in each sub-district in the city of Bandung by presenting information every two years. So, it is a part of visualization data used in the modeling and prediction for the population growth. It can be seen that we can choose the visualization types based on district or year.

\section{c. $\quad$ Prediction page interface}

This page contains information about the prediction of the sub-district population in the city of Bandung which is presented with information in the form of mapping (Fig. 5). There is also a comparison year button and the year of prediction, which is the comparison year button to display information on the population in each sub-district in Bandung in the previous year and the predictive button to display prediction information on population numbers in subdistricts in Bandung City based on the number of years of prediction chosen. As well as a popup that displays information about the population in the sub-district by clicking on the map of the sub-district selected. 


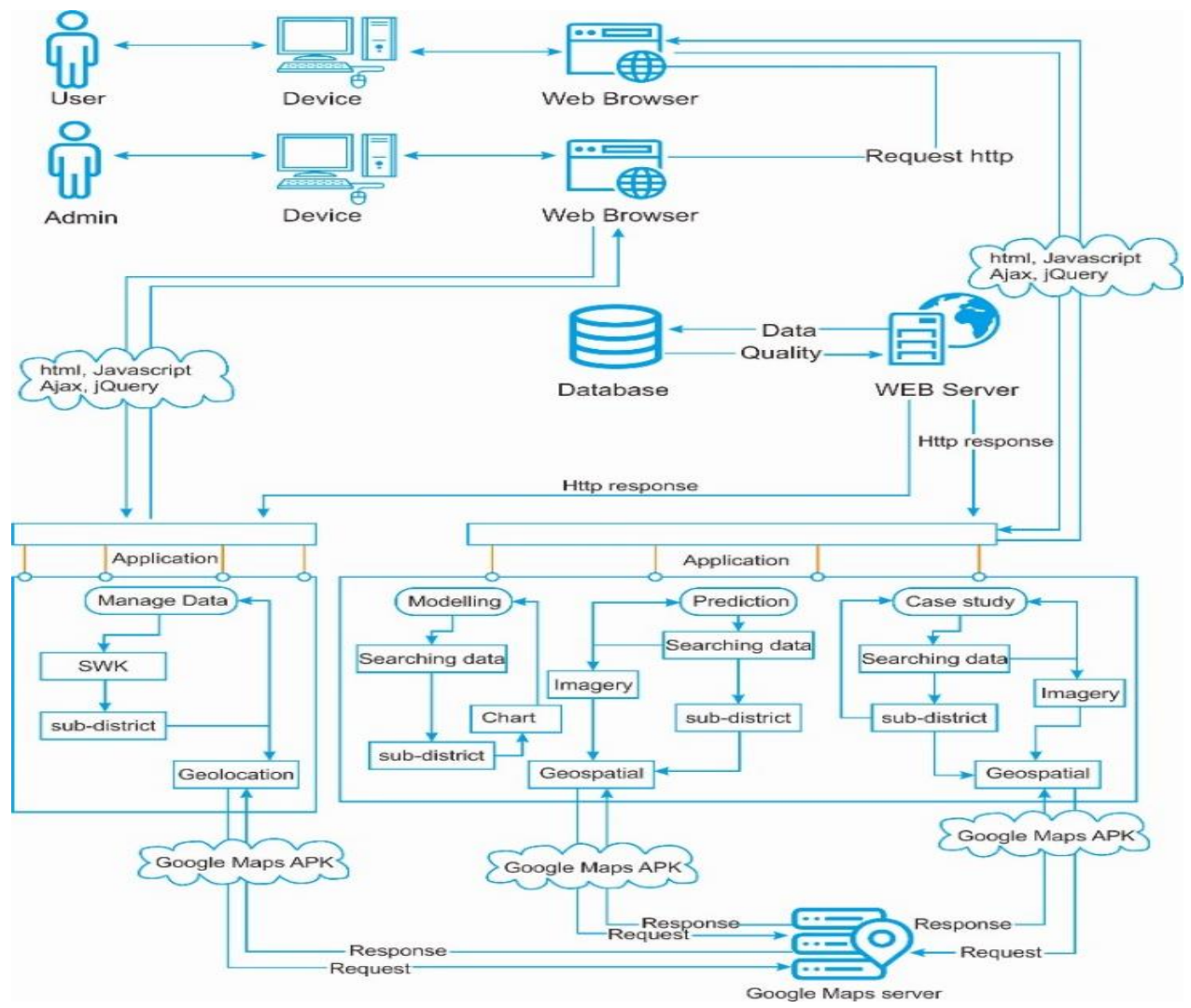

Fig. 2. The architecture of GIS for dissemination and prediction of population in Bandung.

SIC BANDUNC

HOME MODELLING PREDICTION CASESTUDIES

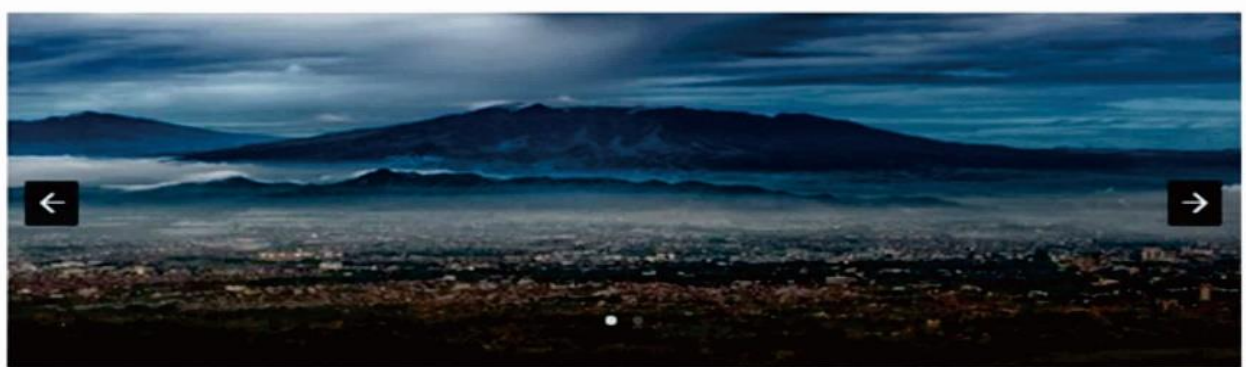

\section{KOTA BANDUNG}

Kota Bandung dikelilingi oleh pegunungan, sehingga bentuk morfologi wilyahnya bagaikan sebuah mangkok raksasa, secara geografis kota ini terletak di tengah-tengah provinsi Jawa Barat, serta berada pada ketinggian $+768 \mathrm{~m}$ di atas permukaan laut, dengan titik tertinggi di berada sebelah Utara dengan ketinggian 1.050 meter di atas permukaan laut dan sebelah Selatan merupakan kawasan rendah dengan ketinggian 675 meter di atas permukaan laut

Fig. 3. Implementation of the homepage interface of the system. 


\begin{tabular}{l|l|l|ll}
\hline YEAR BASED & \multicolumn{2}{c}{ DISTRICT BASED } \\
\cline { 2 - 3 } $2013-2014$ & $2014-2015 ;$ & $\mathbf{2 0 1 5 - 2 0 1 6}$ & $2016-2017 \quad 2017-2018 ;$ \\
\hline
\end{tabular}

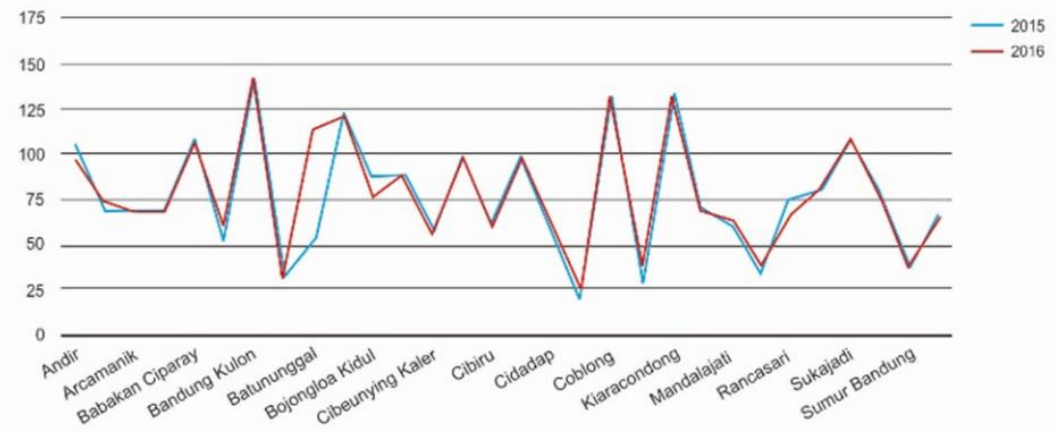

Fig. 4. The population growth in some sub-district in Bandung in 2015 and 2016.

SIG BANDUNC

\section{STARTING POINT}

2017

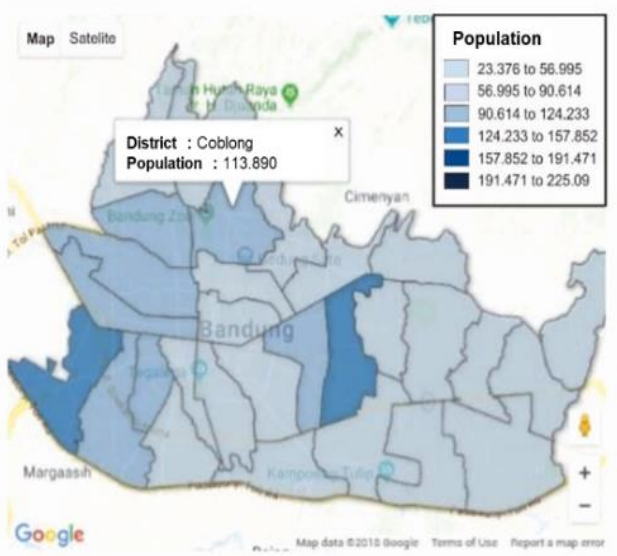

HOME MODELLING PREDICTION CASE STUDIES

Fig. 5. Implementation of the Prediction page interface.

It can be seen that there are two following maps built in the spatial mode: population on a specific year (e.g., in 2017) and longterm prediction of the population growth (e.g., next 30 years). On the left map users can click on a particular district to visualize its chosen population while on the right one we show the prediction map. We can see on Fig. 5 that population growth is represented by changing color, which is darker color. 


\section{d. Interface page for case studies}

Next is the case study page as shown in Fig. 6. This page contains information about density in each sub-district in Bandung City, as well as sub-district information based on the year presented in Table 1. Basically, Fig. 6 presents a comparison between the population and the area. Then, we represent the density on spatial map with different colors. The detailed data can also be seen in the table below on the map.

\section{Ujungberung}
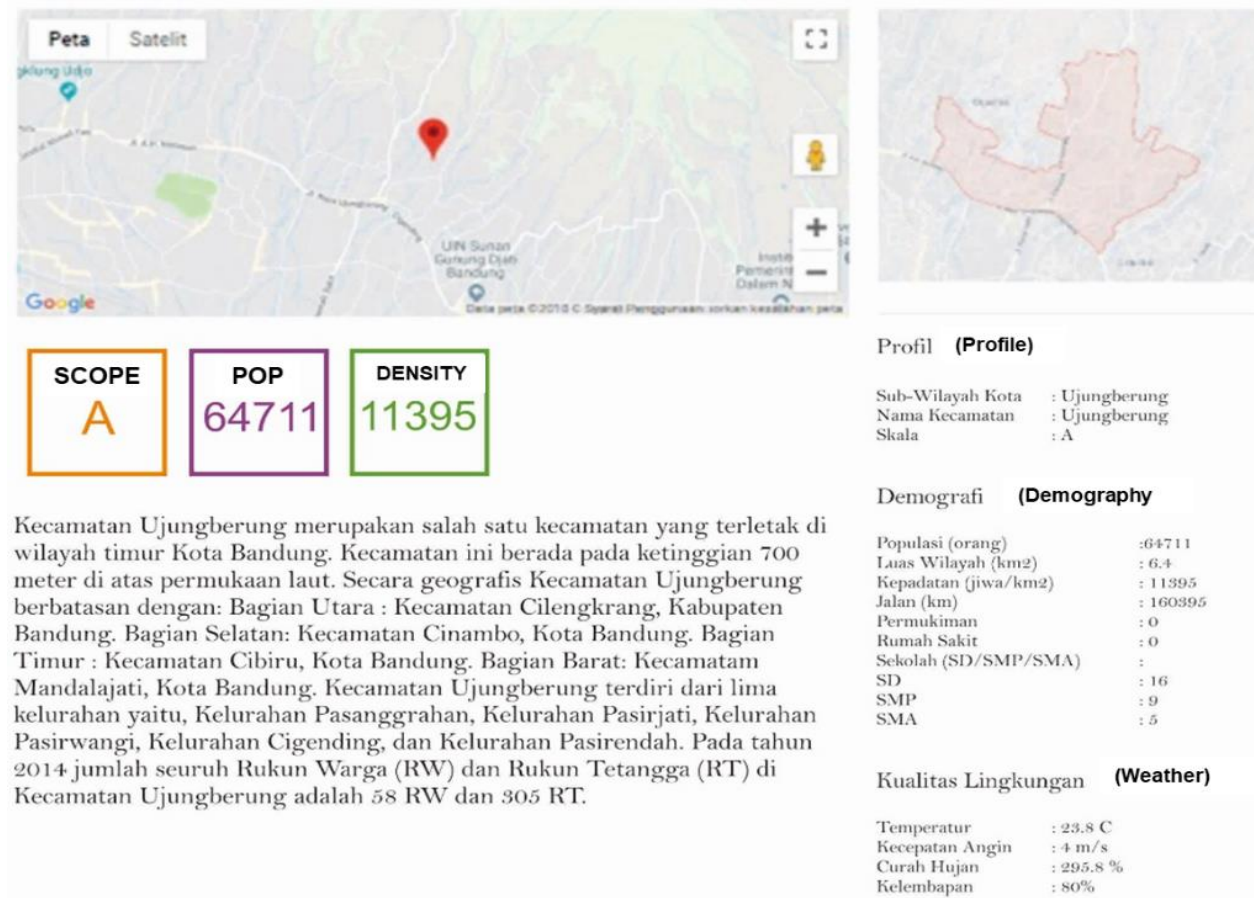

Kecamatan Ujungberung merupakan salah satu kecamatan yang terletak di wilayah timur Kota Bandung. Kecamatan ini berada pada ketinggian 700 meter di atas permukaan laut. Secara geografis Kecamatan Ujungberung berbatasan dengan: Bagian Utara : Kecamatan Cilengkrang, Kabupaten Bandung. Bagian Selatan: Kecamatan Cinambo, Kota Bandung. Bagian Timur : Kecamatan Cibiru, Kota Bandung. Bagian Barat: Kecamatam Mandalajati, Kota Bandung. Kecamatan Ujungberung terdiri dari lima kelurahan yaitu, Kelurahan Pasanggrahan, Kelurahan Pasirjati, Kelurahan Pasirwangi, Kelurahan Cigending, dan Kelurahan Pasirendah. Pada tahun 2014 jumlah seuruh Rukun Warga (RW) dan Rukun Tetangga (RT) di Kecamatan Ujungberung adalah $58 \mathrm{RW}$ dan $305 \mathrm{RT}$.

Fig. 6. Visualization of the density on some district in Bandung.

\section{e. Interface the detail page of Case Studies}

Detail page for a case study is presented in Fig. 7 which contains detailed information in each sub-district in the city of Bandung, i.e. a map of sub-district locations, sub-district boundaries, sub-district scale, sub-district population, sub-district density, sub-district description, subdistrict profile, sub-district demography, and environmental quality in the selected subdistrict as shown above. It can be seen for this case, the sub-district "Ujungberung" has the scale A, 64,711 for the population, and round 11,396 for the density (i.e., calculating from people $/ \mathrm{km}^{2}$ ). Moreover, other relevant information is presented as well in this page, such as the numbers of facilities, environment quality, etc. 


\section{Ujungberung}
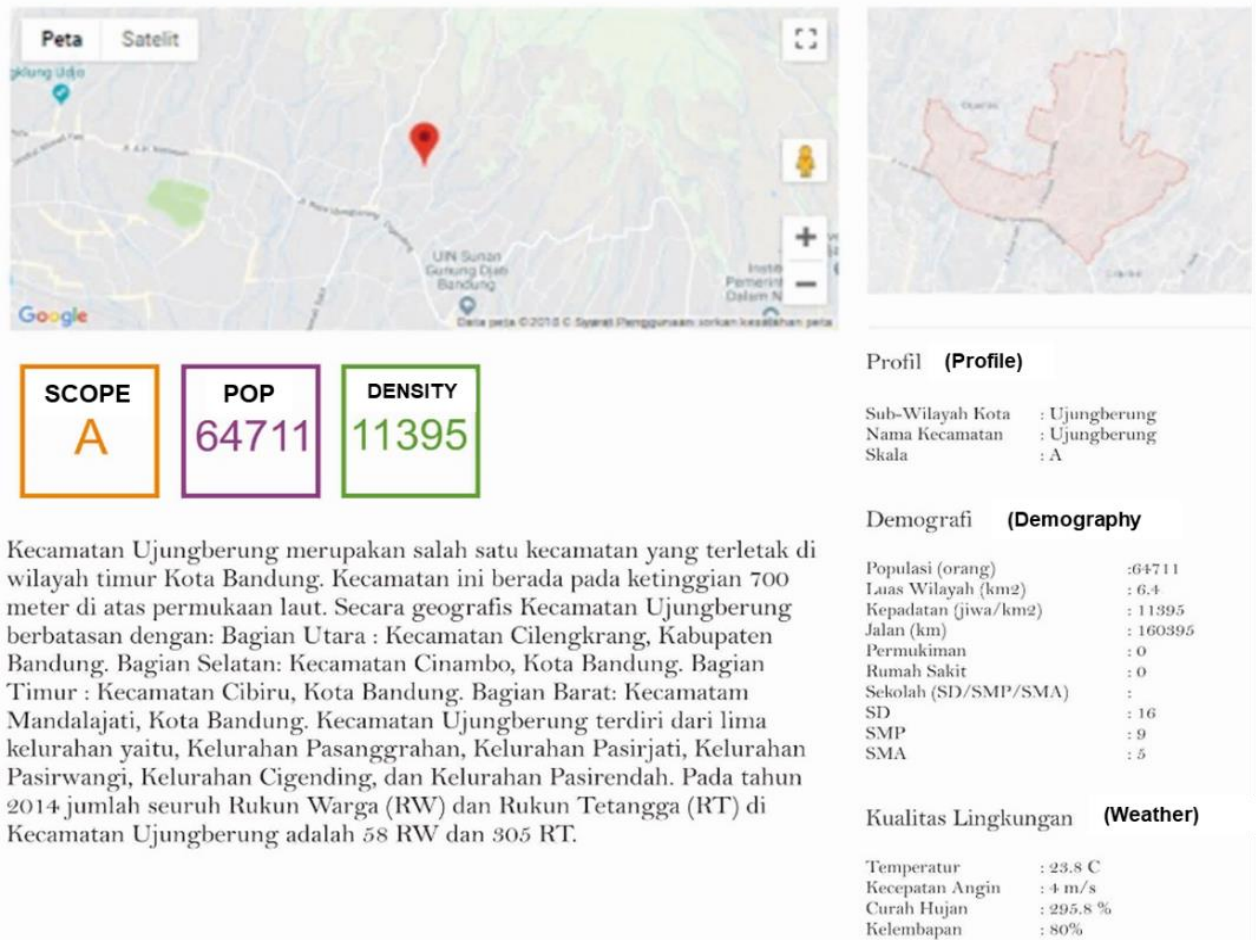

Fig. 7. The resume page about population, density, and other information for the sub-district "Ujungberung" in Bandung.

\section{CONCLUSION}

A GIS mapping the distribution and prediction of the population in the city of Bandung using a web-based biometric model has been made in accordance with the analysis and design. Application specifications that are built consisting of a prediction feature of the population in all districts in the city of Bandung automatically using Geometric methods. A webgis technology is used to visualize the distribution map of population results, population density, and a comparison map between existing population distribution maps. The application can also predictive maps that show changes in the distribution of population distribution in the city of Bandung. In the future, the application will be enhanced to facilitate the process of observing the population distribution and prediction in Bandung city area. Those application will be useful as the spatial decision that outlined in the spatial planning and territory (RTRW) of Bandung. 


\section{REFERENCES}

Baiocchi, V., Lelo, K., Milone, M.V., Mormile, M., Tanga, E. (2013) Accuracy of different georeferencing strategies on historical maps of Rome. Geographia Technica, 8, (1), 10-16.

Brigante, R., Radicioni, F. (2014) Georeferencing of historical maps: GIS technology for urban analysis. Geographia Technica, 9, (1), 10-19.

Chen, J., Pei, T., Shaw, S-L., Lu, F., Li, M., Cheng, S., Liu, X., Zhang, H. (2018) Fine-grained prediction of urban population using mobile phone location data, International Journal of Geographical Information Science. DOI: 10.1080/13658816.2018.1460753.

Costantino, D., Angelini, M.G., Claveri, M., Alfio, V.S. (2016) GIS and DBMS implementation for the development of rural areas of the "One Hundred Masserie" of Crispiano. Geographia Technica. 11, (1), 23-32. DOI: 10.21163/GT_2016.111.04.

Ertug Gunes, A., Kovel, J. P. (2000) Using GIS in emergency management operations. Journal of Urban Planning and Development. 126 (3), 136. DOI: 10.1061/(ASCE)0733-9488(2000).

Harison and Syarif, A. (2016) Sistem Informasi Geografis Pemetaan Sarana Prasarana (GIS for Infrastructure). Jurnal TEKNOIF. ISSN : 2338-2724

Howard, M. (2001) e-Government Across the Globe: How Will "e" Change Government?. Government finance review.

Langford, M. et al. (2008) Urban population distribution models and service accessibility estimation, Computers, Environment and Urban Systems.

Malik, I.B.I., Suparta, W., Dewancker, B.J. (2019) A study of population density in developing countries. Geographia Technica, 14, Special Issue, 201-212.

Paramita, B. (2016) The land-use of Bandung, its density, overcrowded area and public facility toward a compact city. IOP Conference Series: Materials Science and Engineering, 128(012034).

Rahmawati, N., Saputra, R. and Sugiharto, A. (2014) 'Sistem Informasi Geografis Pemetaan Dan Analisis Lahan Pertanian Di Kabupaten Pekalongan' (GIS for agriculture mapping and analysis in Pekalongan Regency), Journal of Informatics and Technology.

Shah, N. and Nerurkar, A. (2012) A GIS Based e-Governance Solution for School Mapping and Educational Micro-Planning - a Case Study of the State of Maharashtra, India. In 9th International Conference on E-Governance (ICEG 2012).

Susanto, A., Kharis, A. and Khotimah, T. (2016) Sistem Informasi Geografis Pemetaan Lahan Pertanian dan Komoditi Hasil Panen Kabupaten Kudus (GIS of Mapping Agricultural Land and Commodities in Kudus). Jurnal Informatika. DOI: 10.26555/jifo.v10i2.a5065.

Zee, J. T. M. Van Der and Jong, B. De (1999) Alignment Is Not Enough: Integrating Business and Information Technology Management with the Balanced Business Scorecard. Journal of Management Information Systems. DOI: 10.1080/07421222.1999.11518249. 